\title{
Preliminary torrefaction of oil palm empty fruit bunch pellets
}

\author{
Bemgba B. Nyakuma ${ }^{1}$, Arshad Ahmad ${ }^{1,2^{*}}$, Anwar Johari ${ }^{1}$, Tuan Amran T. Abdullah ${ }^{1,2}$, \\ Olagoke Oladokun ${ }^{2}$, Ali H. Al-Shatri ${ }^{1,2}$, Adnan Ripin ${ }^{2}$, Afizah Alir ${ }^{2}$ \\ ${ }^{1}$ School of Chemical and Energy Engineering, Faculty of Engineering, Universiti Teknologi \\ Malaysia, 81310, Johor Bahru, Johor, Malaysia. \\ ${ }^{2}$ Centre for Hydrogen Energy, Institute of Future Energy, Universiti Teknologi Malaysia, \\ 81310 Johor Bahru, Johor, Malaysia.
}

\begin{abstract}
Torrefaction of pelletised oil palm empty fruit bunches (OPEFBs) is a promising pretreatment technique for improving its solid biofuel properties and energy recovery potential. Therefore, this paper investigates the torrefaction of OPEFB pellets to examine the effects of temperature and purge gas flow rate on mass yield $\left(\mathrm{M}_{\mathrm{Y}}\right)$, energy yield $\left(\mathrm{E}_{\mathrm{Y}}\right)$, and mass loss $\left(\mathrm{M}_{\mathrm{L}}\right)$. The results revealed that $\mathrm{M}_{\mathrm{Y}}$ and $\mathrm{E}_{\mathrm{Y}}$ decreased due to significant $\mathrm{M}_{\mathrm{L}}$ during torrefaction. Furthermore, significant improvements in the higher heating value (HHV) and energy density $\left(\mathrm{D}_{\mathrm{E}}\right)$ were observed. The torrefaction temperature increased liquid (tar) and gas yields mainly above $300{ }^{\circ} \mathrm{C}$ at the expense of solid products. However, the effect of purge gas flow rate on the torrefaction products was found to be negligible. Consequently, the torrefaction of OPEFB pellets were limited to 250-300 ${ }^{\circ} \mathrm{C}, 30 \mathrm{~min}$, and nitrogen $\left(\mathrm{N}_{2}\right)$ gas flow rate of $200 \mathrm{ml} \mathrm{min}^{-1}$.
\end{abstract}

\section{Introduction}

The growing global demand for crude palm oil (CPO) has increased the cultivation of oil palm (Elaeis guineensis Jacq.) worldwide [1]. In Malaysia, over 20 million tonnes of $\mathrm{CPO}$ are processed from over 75 million tonnes of fresh fruit bunches (FFB) harvested annually [2]. However, with an estimated oil yield of 22\%-23\%, CPO production generates large quantities of oil palm waste (OPW) annually from oil palm mills in Malaysia [3]. Over the years, the growing stockpiles of OPW have become an environmental burden arising largely from uncontrolled tipping or dumping, crude burning, and landfilling of OPW [4]. In addition, poor efficiencies, secondary wastes, and emissions from current conversion technologies have resulted in increased air, land, and water pollution [3].

The outlined problems are largely ascribed to the poor solid biofuel properties of OPW, particularly oil palm empty fruit bunches (OPEFBs). High moisture, heterogeneity, ash, and alkali content of OPEFB along with its low calorific value, energy density, and grindability have hampered efficient energy recovery [5]. Furthermore, poor fuel properties of OPEFB are responsible for operational problems such as sintering, agglomeration, and fouling of gasifiers and biomass boilers [6]. 
Nonetheless, the outlined challenges can be addressed by biomass pretreatment technologies such as pelletisation and torrefaction. The process of pelletisation compacts pulverised biomass into uniform solid fuel with high energy density and calorific value but low moisture [7]. Similarly, torrefaction improves the solid fuel properties of biomass such as hydrophobicity and grindability [8,9]. In principle, torrefaction is a mild pyrolysis process used to pretreat biomass at low pressures, heating rates $\left(<50{ }^{\circ} \mathrm{C} \mathrm{min}\right)$, gas flow rates $\left(<1000 \mathrm{ml} \mathrm{min}^{-}\right)$, and temperatures from 200 to $400{ }^{\circ} \mathrm{C}$ either under inert or oxidative conditions $[10,11]$.

However, previous studies that have examined the torrefaction of OPWs revealed low mass and energy yields $[12,13]$ due to loss of interparticle bonding and overoxidation of loose biomass particles $[10,14]$. However, these challenges can be addressed by the torrefaction of pelletised OPEFB. This will likely address the problems of loss of interparticle bonding, rapid decomposition (overoxidation), and poor yield of pulverised biomass after torrefaction and poor quality pellets after pelletisation. Therefore, this paper seeks to perform a preliminary analysis of the torrefaction of OPEFB pellets in a horizontal fixed bed tubular reactor (FBT). It also examines the effects of temperatures $\left(250-350{ }^{\circ} \mathrm{C}\right)$ and purge gas flow rates $\left(50-200 \mathrm{ml} \mathrm{min}{ }^{-1}\right)$ on mass yield $\left(M_{v}\right)$, energy yield $\left(E_{v}\right)$, energy density $\left(\mathrm{D}_{\mathrm{E}}\right)$, and higher heating value $(\mathrm{HHV})$ of torrefied pellets.

\section{Experimental methods}

Pelletised OPEFBs were acquired from a palm oil mill in Kota Tinggi, Johor, Malaysia. Subsequently, OPEFB pellets were characterised to examine the physicochemical, thermal, and kinetic properties as presented in our previous studies [15-17]. Based on the results, it was observed that OPEFB pellets required further pretreatment to improve its solid biofuel properties for efficient energy recovery [5]. Therefore, OPEFB pellets were pretreated through torrefaction from 250 to $350{ }^{\circ} \mathrm{C}$ (in $25^{\circ} \mathrm{C}$ steps) under non-oxidative conditions (nitrogen $\left(\mathrm{N}_{2}\right)$ ) at $15{ }^{\circ} \mathrm{C}$ min ${ }^{-1}$ in a stainless steel FBT reactor as depicted in Figure 1. Heat was supplied to the reactor during torrefaction through a tube furnace (Model: Lindberg Blue M, USA).

For each test, $15 \mathrm{~g}$ of OPEFB pellets was placed in the FBT reactor and purged with $\mathrm{N}_{2}$ for $15 \mathrm{~min}$ at the selected flow rate of $200 \mathrm{ml} \mathrm{min}{ }^{-1}$. After flushing was completed, the reactor and OPEFB pellets were heated under non-isothermal (dynamic) conditions from room temperature (RT) to the selected torrefaction temperature $\left(250-350{ }^{\circ} \mathrm{C}\right)$. Next, the heating programme was switched to isothermal mode to maintain heating at the selected torrefaction hold time of $30 \mathrm{~min}$. Upon completion of torrefaction, the tube furnace was switched off and the FBT reactor and its contents were cooled to RT. The torrefied OPEFB pellets were subsequently retrieved, weighed, and stored in airtight vessels prior to characterisation. The torrefaction process was evaluated based on the parameters of $M_{r}, E_{\gamma}$, $\mathrm{D}_{\mathrm{E}}$, and HHV, calculated from Equations 1.1 to $1.4[18,19]$.

$$
\begin{gathered}
M_{Y}=\left(\frac{m_{T B}}{m_{R E}}\right) \times 100 \\
E_{Y}=M_{Y} \times\left(\frac{H H V_{T B}}{H H V_{R E}}\right) \\
D_{E}=\left(\frac{E_{Y}}{M_{Y}}\right) \\
H H V=19.85+9.34 \times\left(M_{L}\right)
\end{gathered}
$$


Where the terms $m_{r s}$ represent the mass of torrefied OPEFB pellets, $m_{R B}$ is the mass of raw OPEFB pellets, $\mathrm{M}_{\mathrm{r}}$ is the mass yield, $\mathrm{E}_{\mathrm{\gamma}}$ is the energy yield, $\mathrm{D}_{\mathrm{\varepsilon}}$ is the energy density, $H H V_{r в}$ is the higher heating value of torrefied OPEFB pellets (MJ $\mathrm{kg}^{-1}$ ), and $H H V_{в в}$ is the higher heating value of raw OPEFB pellets (MJ kg-1).

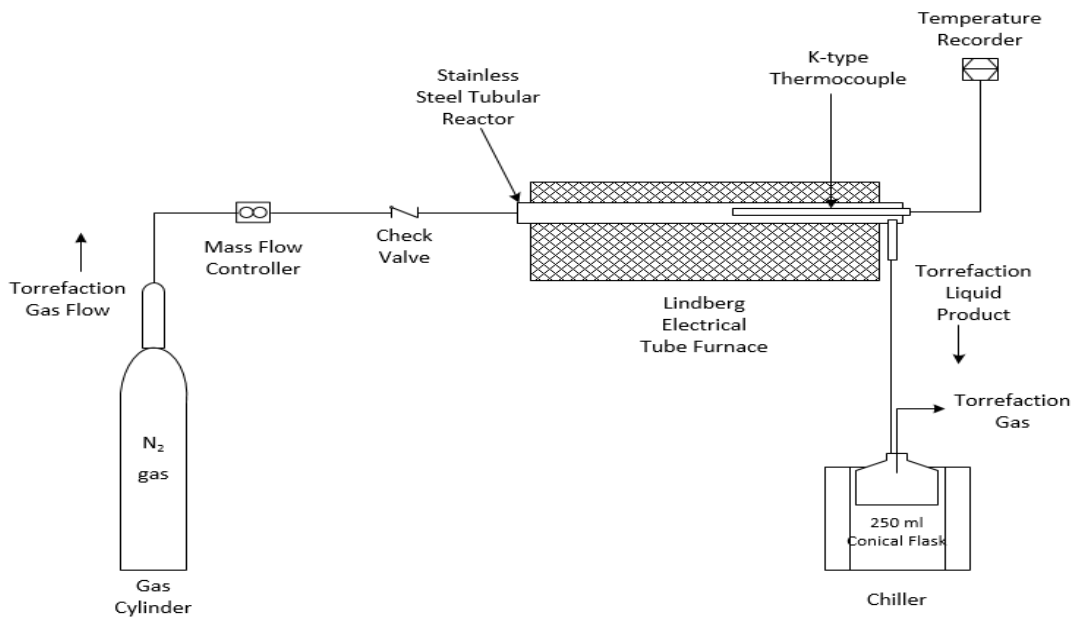

Fig. 1. Schematic diagram for torrefaction of OPEFB pellets.

Lastly, the effect of gas flow rates $\left(50,100\right.$, and $200 \mathrm{ml} \mathrm{min}$ ) on the $\mathrm{M}_{r}$ of torrefaction was examined at $300{ }^{\circ} \mathrm{C}$ for $30 \mathrm{~min}$. The tests were performed to examine the effect of torrefaction purge gas flow rate on the torrefaction of OPEFB pellets in a stainless steel FBT reactor. All tests were performed in duplicate to ensure the accuracy and reliability of the measurements.

\section{Results and discussion}

The values of $\mathrm{M}_{\mathrm{r}}$ and $\mathrm{M}_{\mathrm{L}}$ for the torrefaction of OPEFB pellets in the FBT reactor under $\mathrm{N}_{2}$ gas from $250-350{ }^{\circ} \mathrm{C}$ are presented in Figure 2.

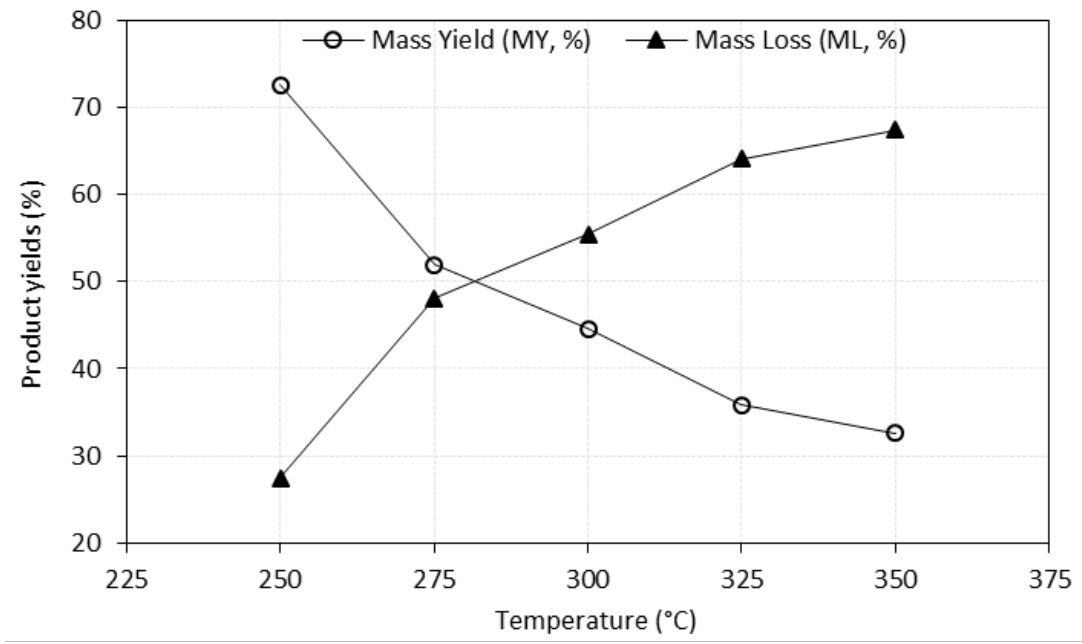

Fig. 2. $\mathrm{M}_{\mathrm{Y}}$ and $\mathrm{M}_{\mathrm{L}}$ for torrefaction of OPEFB pellets. 
As observed in Figure 2, $\mathrm{M}_{\mathrm{r}}$ decreased from $72.61 \%$ to $32.58 \%$ during torrefaction. However, $M_{t}$ increased from $27.39 \%$ to $67.42 \%$. The $M_{\iota}$ is due to the thermal degradation and devolatilisation of hemicellulose, lignin, and volatile matter during torrefaction [20]. The increase in temperature promotes the thermal decomposition of lignocellulosic bonds and volatile matter in OPEFB pellets during torrefaction. Consequently, the pellets undergo drying, devolatilisation, decarboxylation, and depolymerisation, resulting in the loss of moisture, volatiles, $\mathrm{CO}_{2}$, and lignocellulosic components, respectively, during torrefaction. The outlined thermochemical reactions improve hydrophobicity, grindability, and porosity of biomass after torrefaction $[8,9]$. Similarly, torrefaction improves the $E_{\gamma}$, energy density $D_{\mathrm{e}}$, and HHV of the torrefied biomass. Hence, the effect of OPEFB pellets torrefaction on the parameters was examined as presented in Table 1.

Table 1. Torrefaction Parameters for OPEFB Pellets

\begin{tabular}{|c|c|c|c|}
\hline $\begin{array}{c}\text { Torrefaction } \\
\text { Temperature }\left({ }^{\circ} \mathbf{C}\right)\end{array}$ & $\begin{array}{c}\text { Energy Yield } \\
\left(\mathbf{E}_{\mathbf{Y}}, \mathbf{\%}\right)\end{array}$ & $\begin{array}{c}\text { Energy Density } \\
\left(\mathbf{D}_{\mathbf{E}}\right)\end{array}$ & $\begin{array}{c}\text { HHV } \\
(\mathbf{M J} / \mathbf{k g})\end{array}$ \\
\hline 250 & 92.60 & 1.28 & 22.41 \\
\hline 275 & 71.96 & 1.39 & 24.34 \\
\hline 300 & 63.51 & 1.42 & 25.03 \\
\hline 325 & 52.74 & 1.47 & 25.84 \\
\hline 350 & 48.48 & 1.49 & 26.15 \\
\hline
\end{tabular}

As observed, all $D_{E}$ and HHV increased whereas $E_{Y}$ decreased with increasing temperature during torrefaction. Furthermore, $\mathrm{E}_{\mathrm{\gamma}}$ decreased from $92.60 \%$ to $48.48 \%$. However, $\mathrm{D}_{\mathrm{E}}$ increased from 1.28 to 1.49 due to the higher HHV from $22.41-26.15 \mathrm{MJ} \mathrm{kg}$. In addition, the HHV of torrefied pellets is significantly high and comparable to lignite and sub-bituminous coals reported in the literature [21, 22]. This indicates the torrefied pellets have potential synergic characteristics that could promote co-firing or utilisation in boilers. The decrease in $E_{\curlyvee}$ is ascribed to the significant $M_{\llcorner}$resulting from the removal of water, volatiles, and lignocelluloses during torrefaction. $\mathrm{M}_{\mathrm{L}}$ positively affects $\mathrm{HHV}$, thus resulting in higher $\mathrm{D}_{\mathrm{E}}$.

Furthermore, the torrefaction process generated high liquid (tar) and gas yields, particularly above $300{ }^{\circ} \mathrm{C}$. The tar produced was deposited on the walls of the reactor with traces were also found in the liquid product (Figures $3(\mathrm{a}-\mathrm{d})$ ), as also reported in the literature [23, 24].

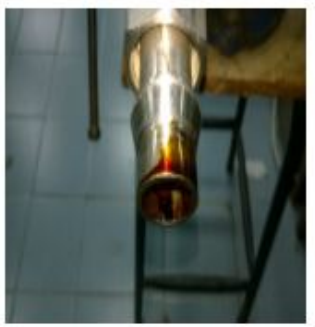

(a)

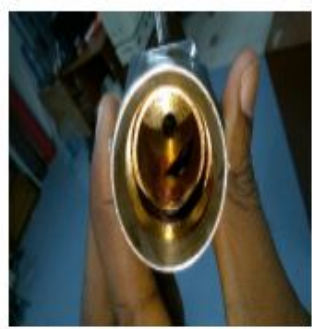

(b)

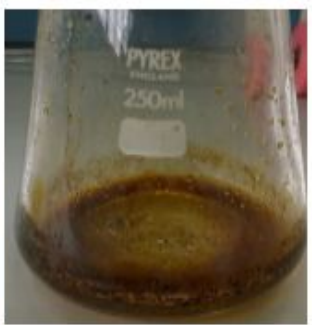

(c)

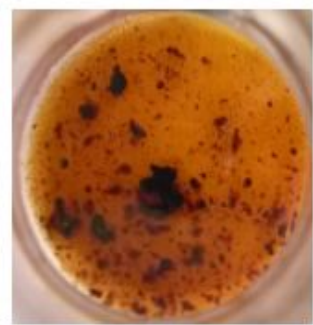

(d)

Fig. 3. Tar deposits formed on equipment/apparatus during OPEFB pellet torrefaction.

Tar is an undesirable torrefaction product that affects biomass conversion efficiency, product selectivity, and the costs of production and cleaning due to the fouling of equipment. The formation of tar is typically attributed to the decomposition of cellulose and lignin $[25,26]$, which are major sources of condensable vapour and tar compounds during 
torrefaction [27]. Therefore, it is imperative to limit OPEFB pellets torrefaction to 250-300 ${ }^{\circ} \mathrm{C}$ to selectively yield HHV and energy dense solid products as opposed to liquid (tar) or gases. Lastly, the effect of purge gas flow rate for torrefaction on $M_{r}$ and $M_{\llcorner}$was examined as presented in Table 2. The torrefaction tests were performed at $300{ }^{\circ} \mathrm{C}$ and $30 \mathrm{~min}$ to examine the effect of purge gas flow rate at 50,100, and $200 \mathrm{ml} \mathrm{min}^{-1}$.

Table 2. Effect of purge gas flow rate on torrefaction parameters

\begin{tabular}{|c|c|c|c|}
\hline $\begin{array}{c}\text { Torrefaction } \\
\text { Temperature }\left({ }^{\circ} \mathbf{C}\right)\end{array}$ & $\begin{array}{c}\text { Gas Flow Rate } \\
(\mathbf{m L} / \mathbf{m i n})\end{array}$ & $\begin{array}{c}\text { Mass Yield } \\
\left(\mathbf{M}_{\mathbf{Y}}, \mathbf{\%}\right)\end{array}$ & $\begin{array}{c}\text { Mass Loss } \\
\left(\mathbf{M}_{\mathbf{L}}, \mathbf{\%}\right)\end{array}$ \\
\hline 300 & 50 & 44.69 & 55.31 \\
\hline 300 & 100 & 45.46 & 54.55 \\
\hline 300 & 200 & 43.55 & 56.45 \\
\hline
\end{tabular}

As observed in Table 2, $\mathrm{M}_{\mathrm{r}}$ and $\mathrm{M}_{\llcorner}$did not differ significantly during the torrefaction of the pellets. On average, the values of $\mathrm{M}_{\mathrm{r}}$ and $\mathrm{M}_{\mathrm{L}}$ were $44.57 \%$ and $55.44 \%$, respectively. The results indicated that the change in flow rate of the purge gas had a negligible effect on $M_{r}$ and $\mathrm{M}_{\llcorner}$. The findings are in good agreement with Asadullah et al. [24] whose study examined the effect of gas flow rates on the torrefaction of palm kernel shell (PKS). Therefore, the gas flow rate for future OPEFB pellet torrefaction experiments should be fixed at $200 \mathrm{ml} \mathrm{min}$.

\section{Conclusion}

This paper presents preliminary test results for the torrefaction of OPEFB pellets. The tests examined the effects of temperature $\left(250-350^{\circ} \mathrm{C}\right)$ and torrefaction purge gas flow rate $(50$, 100 , and $200 \mathrm{ml} \mathrm{min}$ ) for $30 \mathrm{~min}$. The results showed that torrefaction resulted in significant changes in $M_{r}$ and $M_{\llcorner}$along with improvements in $H H V, D_{\varepsilon}$, and $E_{r}$. However, significant liquid (tar) and gas were generated particularly above $300{ }^{\circ} \mathrm{C}$ during torrefaction. Hence, the $300{ }^{\circ} \mathrm{C}$ temperature mark is the limiting temperature for torrefaction of OPEFB pellets. The effect of torrefaction purge gas flow rate was also examined and found to be negligible on $M_{r}$ and $M_{\llcorner}$. Therefore, the preliminary tests demonstrated that future experiments on OPEFB pellets torrefaction should be limited to 250 and $300{ }^{\circ} \mathrm{C}$ for $30 \mathrm{~min}$ under gas flow rate of $200 \mathrm{ml} \mathrm{min}$ to selectively yield solid $\left(\mathrm{M}_{\mathrm{r}}\right)$ products.

The authors gratefully acknowledge the financial support by Universiti Teknologi Malaysia and the Ministry of Higher Education for the LRGS Grant (Vot. No. 4L817). The technical support of Hydrogen and Fuel Laboratory, UTM Johor Bahru campus is also gratefully acknowledged.

\section{References}

1. Yan, W., Nature. 2017, Springer Nature Inc.: USA. p. 306-308.

2. Basiron, Y., European Journal of Lipid Science and Technology, 109(4) (2007)

3. Abdullah, N. and F. Sulaiman, Biomass Now-Sustainable Growth and Use, 1(3) (2013)

4. Foo, K. and B. Hameed, Journal of Hazardous Materials, 172(2-3) (2009)

5. Sulaiman, F., et al., Biomass and Bioenergy, 35(9) (2011)

6. Lahijani, P. and Z.A. Zainal, Bioresource Technology, 102(2) (2011)

7. Nasrin, A., et al., Malaysian Palm Oil Board Information Series, (2006) 
8. Basu, P., Biomass Gasification, Pyrolysis and Torrefaction: Practical Design and Theory. (2) (2013), London, United Kingdom, Academic Press (Elsevier). 530.

9. Chen, W.H., Torrefaction, in Pretreatment of Biomass: Processes and Technologies, A. Pandey, et al., Editors. 2015, Elsevier BV: Oxford, United Kingdom.

10. Chew, J.J. and V. Doshi, Renewable and Sustainable Energy Reviews, 15(8) (2011)

11. Sukiran, M.A., et al., Energy Conversion and Management, 149(2017)

12. Uemura, Y., et al., Fuel, 103(2013)

13. Uemura, Y., et al., Fuel, 90(8) (2011)

14. Stelte, W., et al., biomass and bioenergy, 35(11) (2011)

15. Nyakuma, B., A. Johari, and A. Ahmad, Journal of Applied Sciences, 12(24) (2012)

16. Nyakuma, B.B., et al., Energy Procedia, 52(2014)

17. Nyakuma, B.B., et al., Chemical Engineering Transactions, 45(2015)

18. Bridgeman, T., et al., Fuel, 87(6) (2008)

19. Chen, W.-H., et al., Applied Energy, 160(2015)

20. Nyakuma, B.B., et al., arXiv preprint arXiv:1505.05469, (2015)

21. Vassilev, S.V., C.G. Vassileva, and V.S. Vassilev, Fuel, 158(2015)

22. Nyakuma, B., et al., Petroleum \& Coal, 60(4) (2018)

23. Hilten, R.N., et al., Energy \& Fuels, 27(2) (2012)

24. Asadullah, M., et al., Energy Conversion and Management, 88(2014)

25. Hosoya, T., H. Kawamoto, and S. Saka, Journal of Analytical and Applied Pyrolysis, 83(1) (2008)

26. Yu, H., et al., Fuel, 118(2014)

27. Mohan, D., C.U. Pittman, and P.H. Steele, Energy \& Fuels, 20(3) (2006) 